\title{
THE EFFECT OF QUANTUM LEARNING ASSISTED BY AUDIO VISUAL ON THE SELF EFFICACY OF FIFTH GRADE STUDENTS
}

\author{
Ni Luh Ayu Nita Darmayanti'1, I Gusti Ayu Tri Agustiana², Adrianus I Wayan Ilia Yuda Sukmana ${ }^{3}$ \\ 1,2,3 Fakultas Ilmu Pendidikan, Universitas Pendidikan Ganesha, Singaraja, Indonesia \\ $\underline{1 \text { darmayantiayunita@gmail.com, }}{ }^{2}$ triagustiana.pgsdundiksha@gmail.com, ${ }^{3}$ yudasukmanatp13@gmail.com
}

\begin{abstract}
This study aims to determine the effect of the quantum learning model assisted by audio visual media on the self efficacy of fifth grade student in social studies subject in Elementary School at Gugus III Tembuku, Bangli in the academic year 2019/2020. This research was a quasi experimental study with a nonequivalent posttest only control grup design. The populations in this study were all fifth grade students of Gugus III Tembuku, Bangli in the academic year 2019/2020 with 186 students. The research sample consisted of 34 students in grade 5 of SD Negeri 5 Yangapi as an experimental grup and fifth grade students of SD Negeri 1 Yangapi as a control group with 26 students. This research used data collection methods with non test techniques. The non-test technique used was a questionnaire to look for self-efficacy data for fifth grade students in social studies subjects. The data of this study were analyzed with descriptive analysis techniques and inferential statistics ( $t$-test). The average acquisition of the experimental group questionnaire was 98, while the average results of the control group questionnaire was 89, 96. Based on the significance level of $5 \%$ and $d k=58$, it was obtained $t_{\text {table }}=2.001$ while the value of $t_{\text {count }}=4.935$. So $t_{\text {count }}>t_{\text {table }}$ which proved that $H_{0}$ is rejected and $H_{1}$ was accepted. Thus, it can be concluded that there was an influence of the quantum learning model assisted by audio visual media on the self efficacy of Grade 5 students in Social Sciences of Elementary School Gugus III Tembuku, Bangli in the academic year 2019/2020.
\end{abstract}

Keywords: quantum Learningmodel assisted by audio visual media, self efficacy in social sciences

\section{PENGARUH QUANTUM LEARNING BERBANTUAN AUDIO VISUAL TERHADAP SELF EFFICACY SISWA KELAS V}

\begin{abstract}
ABSTRAK
Penelitian ini bertujuan untuk mengetahui pengaruh model pembelajaran quantum learning berbantuan media audio visual terhadap self efficacy siswa kelas V pada mata pelajaran IPS SD Gugus III Kecamatan Tembuku Kabupaten Bangli tahun pelajaran 2019/2020. Penelitian ini merupakan penelitian eksperimen semu (quasi experiment) dengan rancangan penelitian nonequivalent posttest only control group. Populasi dalam penelitian ini merupakan seluruh siswa kelas V Gugus III Kecamatan Tembuku Kabupaten Bangli tahun pelajaran 2019/2020 sebanyak 186. Sampel penelitian berjumlah 34 siswa pada kelas V SD Negeri 5 Yangapi sebagai kelompok eksperimen dan siswa kelas V SD Negeri 1 Yangapi sebagai kelompok kontrol berjumlah 26 orang siswa. Penelitian inimenggunakan metode pemgumpulan data dengan teknik non tes. Teknik non tes yang digunakan adalah angket untuk mencari data self efficacy siswa kelas V pada mata pelajaran IPS. Data penelitian ini dianalisis dengan teknik analisis deskriptif dan statistic inferensial (uji-t). Perolehan rata-rata hasil angket kelompok eksperimen adalah 98, sedangkan rata-rata hasil angket kelompok kontrol 89, 96. Berdasarkan taraf signifikansi $5 \%$ dan $d k=58$ diperoleh $t_{\text {tabel }}=2.001$ sedangkan didapatkan harga $t_{\text {hitung }}=4.935$. Sehingga $t_{\text {hitung }}>t_{\text {tabel }}$ yang membuktikan bahwa $H_{0}$ ditolak dan $H_{1}$ diterima. Dengan demikian, dapat disimpulkan bahwa terdapat pengaruh model pembelajaran quantum learning berbantuan media audio visual terhadap self efficacy siswa kelas V pada mata pelajaran IPS SD Gugus III Kecamatan Tembuku Kabupaten Bangli tahun pelajaran 2019/2020.
\end{abstract}

Kata Kunci: quantum learning berbantuan media audio visual, self efficacy pada mata pelajaran IPS

\begin{tabular}{|c|c|c|}
\hline Submitted & Accepted & Published \\
\hline 10 Mei 2020 & 14 Juli 2020 & 25 Juli 2020 \\
\hline
\end{tabular}

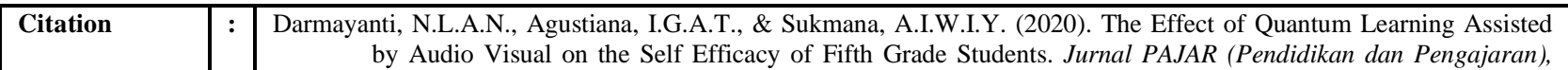
4(4), 792-802. DOI : http://dx.doi.org/10.33578/pir.v4i2.8050.

\section{PENDAHULUAN}

Peran pendidikan sangatlah penting dalam meningkatkan kualitas sumber daya manusia. Menurut Notoatmodjo (2003), hakikat pendidikan bertujuan untuk mengubah tingkah laku peserta didik. Selain itu, kemampuan, watak dan kepribadian yang baik peserta didik akan tumbuh dan berkembang dengan pendidikan serta 
menciptakan generasi penerus bangsa yang berbudi pekerti.

Pendidikan tidak dapat terlepas dari kegiatan pembelajaran. Menurut Dantes (2014), proses pembelajaran merupakan proses aktif dan dinamis. Dalam pembelajaran menghendaki keterlibatan peserta didik dan guru sehingga memungkinkan terjadinya proses belajar pada peserta didik sebagai proses inkuiri reflektif dan memfokuskan perkembangan sebagai tujuan pembelajaran. Pembelajaran merupakan suatu kegiatan, proses dan usaha yang dilakukan secara sadar dan terencana. Proses, kegiatan serta usaha tersebut berasal dari memanipulasi dan berinteraksi dengan sumbersumber belajar agar terjadi proses belajar efektif sehingga peserta didik mengalami perubahan tingkah laku dalam hal kognitif, afektif dan psikomotorik kearah positif.

Pembelajaran pada zaman dahulu sebagian besar didominasi oleh penjelasan atau ceramah dari guru (teacher center) sehingga peserta didik telihat pasif dalam pembelajaran. Pembelajaran seperti itu sudah mulai ditinggalkan dan yang diharapkan pada zaman sekarang ini yaitu pembelajaran yang berpusat pada peserta didik (student center). Maksudnya, yang lebih berperan aktif dalam pembelajaran adalah peserta didik. Peserta didik lebih dominan dalam pembelajaran dan guru berperan sebagai perancang, pengontrol, serta fasilitator dalam proses pembelajaran.

Terdapat beberapa faktor yang mempengaruhi capaian belajar peserta didik. Yang memegang peran penting dalam kehidupan sehari-hari dan mempengaruhi capaian belajar salah satunya yaitu self efficacy. Menurut Bandura (dalam Subaidi, 2016), self efficacy adalah kepercayaan seorang atas kemampuannya dalam mengorganisasi dan menyelesaikan suatu tugas atau masalah yang diperlukan untuk mencapai hasil tertentu. Peserta didik yang mempunyai self efficacy tinggi dapat menyelesaikan tugas dan masalah yang dihadapi dalam proses pembelajaran. Sedangkan, peserta didik yang memiliki self efficacy yang rendah cenderung mudah menyerah saat mendapatkan tugas dan masalah yang dihadapi saat proses pembelajaran.

Ketika dilakukan wawancara bersama dengan sebagian besar guru kelas di Gugus III, Kecamatan Tembuku, Kabupaten Bangli pada tanggal 19 Oktober dan 21 Oktober 2019, diperoleh hasil wawancara yaitu 1) pelajaran IPS dianggap sebagai pelajaran yang membosankan oleh peserta didik, 2) kurangnya media pembelajaran, 3) kurangnya self efficacy siswa dalam pembelajaran, 4) banyak peserta didik yang tidak memperhatikan penjelasan guru saat proses pembelajaran. Selain wawancara bersama guru kelas, juga dilakukan observasi yang ditemukan beberapa hal yang berkaitan dengan pembelajaran yaitu 1) guru lebih banyak menjelaskan materi dengan ceramah, memberi contoh, diskusi, dan tanya jawab dalam pembelajaran 2) guru jarang melakukan kreasi untuk menggunakan model pembelajaran yang bervariasi, kreatif dan inovatif, 3) guru kurang melatih keterampilan berpikir kreatif peserta didik, 4) peserta didik kurang percaya diri dalam menyampaikan pendapat dalam pembelajaran, 5) saat proses pembelajaran, khususnya saat pembelajaran IPS sebagian besar peserta didik yang tidak memperhatikan saat guru menjelaskan.

Hal yang harus diperhatikan adalah self efficacy peserta didik sebab self efficacy sangatlah penting. Apabila peserta didik mempunyai self efficacy rendah, maka ia cenderung memiliki pandangan bahwa tugas atau masalah yang ia hadapi lebih sulit dari yang sebenarnya. Sejalan dengan pernyataan Warsito (dalam Amanda, 2014) yang menyatakan bahwa peserta didik dengan self efficacy rendah beranggapan sesuatu lebih sulit dari kenyataannya sehingga peserta didik mengurahi ketekunan dan usahanya untuk memecahkan suatu permasalahan. Sebaliknya, peserta didik yang memiliki self efficacy yang tinggi akan melaksanakan tugas dengan penuh tanggung jawab, tekun, ulet, dan berusaha dalam menyelesaikan tugas yang diberikan. Namun kenyataan dilapangan, kurangnya self efficacy peserta didik di Gugus III Kecamatan Tembuku Kabupaten Bangli berpengaruh pada hasil 
belajar khususnya pada mata pelajaran IPS yang rata-rata nilai berada pada kategori sedang.

Untuk mengatasi kurangnya self efficacy peserta didik, dapat diterapkan model pembelajaran yang memotivasi peserta didik agar aktif, dan meningkatkan kepercayaan diri sehingga mampu menyelesaikan sesuatu secara maksimal (self efficacy). Sehingga peserta didik mempunyai semangat yang tinggi yang bermuara pada meningkatnya hasil belajar peserta didik. Salah satu model pembelajaran yang dapat digunakan untuk meningkatkan self efficacy peserta didik pada mata pelajaran IPS yaitu model quantum learning.

Quantum learning yaitu model kiatkiat, petunjuk, strategi, dan seluruh proses belajar yang dapat mempertajam pemahaman dan daya ingat peserta didik, serta memnjadikan belajar sebagai suatu proses yang menyenangkan dan bermanfaat (Thobroni, 2015). Sejalan dengan pendapat Putra (2019) yang meyatakan bahwa, quantum learning merupakan model pembelajaran yang membiasakan peserta didik belajar menyenangkan dan bermanfaat. Dimana dalam pembelajaran tersebut memadukan berbagai sugesti dan interaksi positif. Guru memberikan saran-saran yang mampu memacu peserta didik untuk belajar dan secara langsung dapat mempengaruhi self efficacy peserta didik. Terkait dengan penerapan model pembelajaran quantum learning, Putra (2019) telah melakukan penelitian yang menunjukan bahwa terdapat pengaruh model pembelajaran quantum learning terhadap hasil belajar IPS.

\section{KAJIAN TEORETIS}

Self efficacy merupakan kepercayaan seseorang terhadap kemampuandiri sendiri agar berhasil mencapai tujuan tertentu. Menurut Manuntung (2018), self efficacy adalah inti dari social cognitive teori yang dikemukakan oleh Albert Badura yang menekankan peran belajar observasional. Self efficacy adalah keyakinan seseorang dalam kemampuannya untuk melakukan suatu bentuk kontrol terhadap fungsi diri sendiri dan kejadian dalam lingkungan.
Pengoptimal model pembelajaran quantum learning dapat diterapkan dengan menggunakan bantuan media pembelajaran. Salah satu media pembelajaran yang dapat diterapkan yaitu media audio visual. Jika model pembelajaran quantum learning diterapkan berbantuan dengan media audio visual maka pembelajaran tersebut dapat menarik minat peserta didik dan ikut serta dalam pembelajaran sehingga dapat meningkatkan self efficacy peserta didik. Lebih lanjut lagi Asyhar (2012) menyatakan bahwa, media audio visual adalah media yang dapat menampilkan unsur suara (audio) dan gambar (visual) secara bersamaan pada saat mengkomunikasikan pesan atau informasi. Media audio visual merupakan media yang dapat digunakan untuk mempermudah pemahaman materi melalui indera penglihatan dan indera pendengaran, sehingga dapat mempermudah memahami sesuatu dan memperkuat ingatan peserta didik. Media audio visual yang dimaksud yaitu film atau video tentang self efficacy.

Berdasarkan uraian permasalahan di atas, sehingga dilakukan penelitian dengan judul Pengaruh Model Pembelajaran Quantum Learning Berbantuan Media Audio Visual Terhadap Self Efficacy Siswa Kelas V Pada Mata Pelajaran IPS SD Gugus III Kecamatan Tembuku Kabupaten Bangli. Tujuan penelitian ini yaitu untuk mengetahui pengaruh model pembelajaran quantum learning berbantuan media audio visual terhadap self efficacy siswa kelas V pada mata pelajaran IPS SD Gugus III Kecamatan Tembuku Kabupaten Bangli tahun pelajaran 2019/2020.

Menurut Fattah (2017), efikasi diri (self efficacy) memiliki hubungan dengan keyakinan individu terhadap kompetensi dan kemampuan diri. Secara spesifik, keyakinan individu terhadap kemampuan untuk menyelasaikan suatu tugas secara berhasil. Individu yang memiliki self efficacy tinggi sangat yakin dengan kemampuan kinerjanya.

Berdasarkan pendapat diatas, dapat disintesiskan bahwa self efficacy yaitu keyakinan 
atau kepercayaan individu terhadap kemampuan dan kompetensi diri sendiri untuk menyelasaikan suatu tugas secara maksimal. Menurut Mukhid (2009: 110), dengan self efficacy yang tinggi membantu perasaan tenang dalam mendekati tugas dan kegiatan yang sulit. Sebaliknya, orang yang meragukan kemampuan dirinya, mereka dapat percaya bahwa sesuatu lebih sulit dari pada kenyataaanya. Menurut Mukhid (2009), self efficacy dalam beberapa hasil studi menunjukkan adanya hubungan dengan prestasi akademik di sekolah. Peserta didik yang memiliki self efficacy rendah untuk belajar mungkin menghindari tugas, sedang peserta didik yang menilai keyakinan dirinya (self efficacy) tinggi lebih mungkin berpartisipasi.

Teori self efficacy menyatakan bahwa tingkatan dan kekuatan self efficacy akan menentukan: 1) seseorang akan melakukan sesuatu atau tidak, 2) seberapa banyak usaha yang dilakukan, dan seberapa lama usaha tersebut dilakukan. Teori self efficacy tidak hubungan dengan keterampilan (skill) yang dimiliki seseorang tetapi berhubungan dengan keputusan yang mereka ambil yang berkaitan dengan keterampilan.

Self efficacy individu dapat berkembang melalui beberapa sumber. Sumber self efficacy tersebut dapat menyebabkan self efficacy seseorang menjadi tinggi atau merendah. Menurut Bandura (dalam Mukhid, 2009), terdapat empat sumber utama yang berpengaruh terhadap self efficacy, yaitu penguasaan atas pengalaman yang menetap, pengalaman yang dirasakan sendiri, bujukan sosial, dan keadaan psikologis atau emosi. Keempat sumber self efficacy tersebut dapat dijelaskan sebagai berikut (Mukhid, 2009).

Dalam self efficacy terdapat beberapa dimensi yang dapat mengklasifikasikan tingkat self efficacy seseorang. Hal ini berkaitan dalam menentukan seberapa besar atau kecil self efficacy individu dalam menghadapi dan menyelesaikan masalah. Beberapa dimensi efikasi diri (self efficacy) yang dikemukakan oleh Bandura (dalam Utari, 2016) yaitu level, generality, dan strength.

Menurut Huda (2014), quantum learning merupakan model pembelajaran yang membiasakan belajar menyenangkan. Penerapan model pembelajaran ini diharapkan dapat meningkatkan minat belajar peserta didik sehingga pada akhirnya peserta didik dapat meningkatkan hasil belajar secara menyeluruh. Menurut Lafudin (2014), langkah-langkah atau sintaks pembelajaran quantum learning menggunakan istilah TANDUR yaitu Tumbuhkan, Alami, Namai, Demonstrasikan, Ulangi, dan Rayakan.

Model quantum learning membuat belajar menyenangkan. Menurut Santoso (2011), menyenangkan dalam hal belajar pada dasarnya dapat dilihat dari: 1) tidak merasa tertekan; 2) bebas mengemukakan pendapat; 3) tidak mengantuk; 4) bebas mencari objek; 5) tidak jemu; 6) berani berpendapat; 7) belajar sambil bermain; 8) banyak ide; 9) santai tapi serius (serius tapi santai); 10) dapat berkomunikasi dengan orang lain; 11) tidak merasa canggung; 12) belajar di alam bebas; dan 13) tidak takut. Salah satu media pembelajaran yang dapat digunakan untuk membantu penyampaian materi di sekolah dasar yaitu media audio visual.

Hal ini sesuai dengan pernyataan Awasthi (2014), "At primary level teaching can be effective when it activates all the sensory organs of child. Using audio visual aids can be useful for making learning easy, effective and permanent". Artinya, di tingkat sekolah dasar pembelajaran dapat berjalan efektif ketika mengaktifkan semua organ indera anak. Menggunakan alat bantu Audio Visual dapat berguna untuk membuat pembelajaran menjadi mudah, efektif dan permanen. Suprijanto (dalam Mayasari, 2019) berpendapat bahwa, media audio visual mempunyai kemampuan yang lebih baik ketika digunakan dalam pembelajaran, karena sekaligus mencakup media auditif (mendengar) dan visual (melihat).

Menurut Asyhar (2012), media audio visual dapat dibedakan menjadi dua macam, yakni: 1) audio visual murni yaitu baik unsur suara maupun unsur gambar berasal dari satu sumber seperti video kaset; dan 2) audio visual tidak murni yaitu unsur suara dan unsur gambarnya berasal dari sumber yang berbeda. Misalnya film bingkai suara, dimana unsur gambarnya berasal 
dari slides proyektor dan unsur suaranya berasal dari tape recorder. Jadi, dapat disimpulkan bahwa media audio visual adalah media yang memiliki unsur gerak dan suara sehingga memiliki

\section{METODE PENELITIAN}

Penelitian ini dilaksanakan di Gugus III Kecamatan Tembuku, Kabupaten Bangli. Penelitian ini dirancang pada kelas V semester genap tahun pelajaran 2019/2020. Pelaksanaan penelitian pada masing-masing sampel dilakukan mulai bulan Januari sampai Maret 2020 dengan perlakuan sebanyak 6 kali pada kelompok kemampuan yang lebih baik ketika digunakan dalam pembelajaran karena penyampaian materi dengan media audio visual dapat didengar dan dilihat sekaligus.

Tabel 1. Desain Penelitian

\begin{tabular}{ccc}
\hline Kelompok & Perlakuan & Post test \\
\hline Ekperimen & $\mathrm{X}_{1}$ & $\mathrm{O}_{1}$ \\
Kontrol & - & $\mathrm{O}_{2}$ \\
\hline
\end{tabular}

Dimodifikasi dari Gall, et al (dalam Dantes, 2017)

Keterangan:

$\mathrm{X}_{1}$ : perlakuan dengan model pembelajaran quantum learning berbantuan media audio visual

- $\quad$ : perlakuan yang tidak menggunakan model pembelajaran quantum learning berbantuan media audio visual

$\mathrm{O}_{1} \quad$ : Test akhir (post-test) kelompok eksperimen

$\mathrm{O}_{2} \quad$ : Test akhir (post-test) kelompok kontrol

Populasi merupakan keseluruhan subjek penelitian. Menurut Koyan (2012), populasi merupakan himpunan dari unsur-unsur yang sejenis. Populasi dalam penelitian ini sebanyak 186 orang peserta didik. Jumlah populasi diperoleh dari seluruh peserta didik kelas V di SD Gugus III Kecamatan Tembuku Kabupaten Bangli tahun pelajaran 2019/2020. Untuk mengetahui kemampuan peserta didik kelas $\mathrm{V}$ terlebih dahulu dilakukan uji kesetaraan terhadap hasil belajar ulangan tengah semester peserta didik menggunakan uji ANAVA satu jalur. Hasil yang diperoleh berdasarkan uji kesetaraan tidak terdapat perbedaan secara signifikan hasil ulangan tengah semester peserta didik.
Pengambilan sampel pada penelitian ini menggunakan teknik simple random sampling dengan teknik undian. Sehingga diperoleh bahwa kelas V SDN 5 Yangapi sebagai kelas eksperimen dengan jumlah peserta didik 34. Sedangkan kelas V SDN 1 Yangapi sebagai kelas Eksperimen dengan jumlah 26 orang peserta didik. Penerapan model pembelajaran quantum learning berbantuan media audio visual dilaksanakan pada kelas eksperimen. Sedangkan pada kelas kontrol pembelajaran diterapkan tanpa model pembelajaran quantum learning berbantuan media audio visual.

Pengumpulan data pada penelitian ini yaitu self efficacy peserta didik pada mata pelajaran IPS. Metode yang digunakan untuk mengumpulkan data yaitu metode non tes dengan angket. Angket self efficacy yang digunakan terdiri dari pernyataan positif dan pernyataan negatif yang secara keseluruhan berjumlah 30 butir pernyataan. Angket diberikan kepada peserta didik setelah pelaksanaan pembelajaran di kelas, baik pada kelompok eksperimen maupun pada kelompok kontrol. Setiap item soal diberikan skor dengan rentangan satu sampai empat. Kemudian skor tersebut dijumlahkan supaya didapatkan skor self efficacy. Terdapat 
tiga dimensi self efficacy yaitu level, generality, dan strength.

Setelah pengumpulan data selesai, data tersebut dianalisis secara bertahap dengan menggunakan statistik deskriptif dan statistik inferensial. Menurut Agung (2015), statistik deskriptif berfungsi untuk membuat data bermakna, yang dapat disajikan dengan berbagai bentuk. Selain itu, statistik deskriptif digunakan un tuk memberikan deskripsi atau gambaran terhadap objek penelitian yang didapatkan melalui data sampel atau populasi penelitian untuk menarik kesimpulan. Statistik deskriptif digunakan untuk mendeskripsikan self efficacy peserta didik pada mata pelajaran IPS pada kelompok eksperimen yang diberikan perlakuan model pembelajaran quantum learning berbantuan media audio visual dan kelompok

\section{HASIL DAN PEMBAHASAN}

Data hasil angket self efficacy yang sudah dikumpulkan dari kelompok ekperimen dengan diberikan perlakuan model pembelajaran quantum learning berbantuan media audio visual. Sedangkan dari kelompok kontrol tidak diberikan perlakuan model pembelajaran quantum learning berbantuan media audio visual. Kelompok eksperimen yaitu peserta didik kelas V SDN 5 Yangapi dengan jumlah 34 orang peserta didik. Data hasil pengukuran angket yang berjumlah 30 butir pernyataan positif dan negatif menunjukan skor tertinggi 109 dan skor terendah 81 dengan rentangan skor 1 sampai 4.

Analisis deskriptif yang dilakukan pada hasil angket self efficacy peserta didik pada mata pelajaran IPS kelompok eksperimen yang kontrol dengan tidak memberikan perlakuan model pembelajaran quantum learning berbantuan media audio visual. Statistik deskriptif yang dilakukan meliputi, mean, median, modus, dan standar deviasi.

Analisis statistik inferensial adalah teknik analisis data yang digunakan untuk menganalisis data sampel dari populasi. Hasil dari analisis tersebut akan digeneralisasikan kepada populasi tempat dimana sampel tersebut berasal (Koyan, 2012). Adapun statistik inferensial yang digunakan sebelum melaksanakan uji hipotesis terlebih dahulu dilakukan uji asumsi meliputi uji normalitas dan uji homogenitas varians. Selanjutnya dilakukan uji hipotesis dengan menggunakan analisis uji-t (independen $t$ test).

dibelajarkan dengan model pembelajaran quantum learning berbantuan media audio visual diperoleh Mean $=98$, Modus $=98.625$, Median $=96.181$, dan standar deviasi $=6,010$.

Kelompok kontrol yaitu peserta didik kelas V SDN 1 Yangapi dengan jumlah 26 orang peserta didik. Data hasil pengukuran angket yang berjumlah 30 butir pernyataan positif dan negative menunjukan skor tertinggi 102 dan skor terendah 74 dengan rentangan skor 1 sampai 4 . Setelah data yang dikumpulkan dilakukan analisis diperoleh Mean $=89.961$, Modus $=$ 90.642, Median $=88.667$, dan standar deviasi $=6.557$. Ringkasan perhitungan dari kelompok eksperimen dan kontrol disajikan dalam tabel 2 berikut.

Tabel 2. Deskripsi data kelompok eksperimen dan kelompok kontrol

\begin{tabular}{ccc}
\hline Sumber & Eksperimen & Kontrol \\
Variansi & 109 & 81 \\
Skor Maksimal & 102 & 74 \\
Skor Minimal & 98 & 89.96 \\
Mean & 98.62 & 90.64 \\
Modus & 96.18 & 88.66 \\
Median & 6.01 & 6.55 \\
Standar Deviasi & & \\
\hline
\end{tabular}


Berdasarkan hasil perhitungan analisis statistik deskriptif selanjutnya dilakukan uji asumsi sebelum uji hipotesis. Uji prasyarat meliputi uji normalitas dan uji homogenitas. Uji normalitas sebaran data dilakukan dengan maksud untuk meyakinkan bahwa sampel benar-benar berasal dari populasi yang berdistribusi normal pada dua kelompok data dalam penlitian ini, yaitu (1) self efficacy kelas eksperimen dan (2) self efficacy kelas kontrol. Uji normalitas sebaran data dilakukan dengan bantuan SPSS-21.0 for windows uji statistik Kolmogrov-Smirnov pada taraf signifikan 0.05. Apabila nilai signifikan lebih besar daripada signifikansi $(\alpha)$ maka sampel berasal dari populasi berdistribusi normal.

Tabel 3. Rekapitulasi Hasil Uji Normalitas Sebaran Data

\begin{tabular}{cccccc}
\hline No & Kelompok Data & Total Sampel & $\mathbf{X}^{2}$ hitung & $\mathbf{X}^{2}$ tabel & Kesimpulan \\
\hline 1 & Eksperimen & 34 & 0.51 & 0.05 & Normal \\
2 & Kontrol & 26 & 0.83 & 0.05 & Normal \\
\hline
\end{tabular}

Berdasarkan tabel 3 hasil perhitungan menunjukan angket kelompok eksperimen dan kontrol dengan menggunakan SPSS 21.0, dari output analisis menunjukkan nilai kolmogrov Smirnov self efficacy adalah 0.516. Sedangkan pada kelas kontrol menunjukkan nilai kolmogrov Smirnov self efficacy adalah 0.837. Oleh karena itu nilai probabilitas kedua nilai signifikan > 0.05 , maka data hasil angket kelompok eksperimen dan kontrol berdistribusi "normal".

Uji homogenitas dimaksud untuk memperlihatkan bahwa dua atau lebih kelompok data sampel berasal dari populasi yang memiliki varians sama atau homogenitas. Uji homogenitas varians menggunakan bantuan program SPSS121.0 for windows pada taraf signifikan 0,05 . Uji homognitas menggunakan Test of Homogeneity of Variance menghasilkan angka signifikan self efficacy sebesar 0,588. "Data dikatakan memiliki varians yang homogen jika nilai probabilitasnya lebih dari 0.05 . Suatu data tidak homogeny apabila signifikansi yang dilakukan hasilnya kurang dari 0.05 (Candiasa, 2010). Oleh karena itu nilai probabilitas kedua nilai signifikan $>0.05$, maka data hasil angket kelompok eksperimen dan kontrol adalah "homogen".

Setelah dilakukan uji normalitas dan uji homogenitas selanjutnya dilakukan uji hipotesis dengan uji-t (independen $t$-test) dengan berbantuan program SPSS-121.0 for windows. Uji hipotesis bertujuan untuk membuktikan pernyataan yang telah dibuat dan menarik kesimpulan mengenai pengaruh model pembelajaran quantum learning berbantuan media audio visual terhadap self efficacy peserta didik kelas $\mathrm{V}$ pada mata pelajaran IPS . Hasil uji hipotesis disajikan dalam tabel 4 berikut.

Tabel 4. Hasil uji-t

\begin{tabular}{ccccccccc}
\hline & & \multicolumn{3}{c}{$\begin{array}{c}\text { Levene's Test for } \\
\text { Equality of } \\
\text { Variances }\end{array}$} & & \multicolumn{3}{c}{ t-test for Equality of Means } \\
& F & Sig. & T & Df & $\begin{array}{c}\text { Sig. (2- } \\
\text { tailed) }\end{array}$ & $\begin{array}{c}\text { Mean } \\
\text { Difference }\end{array}$ & $\begin{array}{c}\text { Std. Error } \\
\text { Difference }\end{array}$ \\
\hline Self Efficacy & $\begin{array}{c}\text { Equal variances } \\
\text { assumed } \\
\text { Equal variances } \\
\text { not assumed }\end{array}$ & 0.297 & 0.588 & 4.935 & 58 & 0.000 & 8.03846 & 1.62876 \\
& & & 4.877 & 51.375 & 0.000 & 8.03846 & 1.64808 \\
\hline
\end{tabular}


Berdasarkan tabel 4, didapatkan nilai signifikan self efficacy pada kolom Corrected Model sebesar 0.000 dan lebih kecil dari 0.05. Selanjutnya diperoleh $\mathrm{t}_{\text {hitung }}$ sebesar 4.935 sedangkan $\mathrm{t}_{\text {tabel }}$ pada taraf signifikansi $5 \%$ serta $\mathrm{dk}$ $=58$ adalah 2.001. Hal ini berarti $t_{\text {hitung }}$ lebih besar dari $t_{\text {tabel }}\left(t_{\text {hitung }}>t_{\text {tabel }}\right)$, sehingga dapat disimpulkan bahwa hipotesis nol $\left(\mathrm{H}_{0}\right)$ ditolak dan hipotesis alternative $\left(\mathrm{H}_{1}\right)$ diterima. Hal ini berarti bahwa terdapat pengaruh yang signifikan model pembelajaran quantum learning berbantuan media audio visual terhadap self efficacy pada mata pelajaran IPS siswa kelas V SD Gugus III Kecamatan Tembuku Kabupaten Bangli Tahun Pelajaran 2019/2020.

Berdasarkan deskripsi data hasil penelitian, kelompok peserta didik yang mengikuti pembelajaran menggunakan model pembelajaran quantum learning berbantuan media audio visual memiliki skor self efficacy yang lebih tinggi dibandingkan dengan peserta didik yang mengikuti pembelajaran tanpa model pembelajaran quantum learning berbantuan media audio visual. Berdasarkan analisis sebaran data menggunakan uji-t (independen t-test), didapatkan nilai thitung lebih besar dari pada $t_{\text {tabel }}\left(t_{\text {hitung }}>t_{\text {tabel }}\right)$, sehingga terdapat pengaruh yang signifikan self efficacy peserta didik antara kelompok yang mengikuti pembelajaran menggunakan model pembelajaran quantum learning berbantuan media audio visual dengan kelompok peserta didik yang tidak mengikuti model pembelajaran quantum learning berbantuan media audio visual.

Hal tersebut dipengaruhi oleh beberapa tahapan (sintaks) pembelajaran quantum learning. Menurut Lafudin (2014: 153), langkah-langkah atau kerangka rancangan pembelajaran quantum learning menggunakan istilah TANDUR yaitu tumbuhkan, alami, namai, demonstrasikan, ulangi, dan rayakan. Adapun temuan yang didapat di kelompok eksperimen dengan pelaksanaan pembelajaran menggunakan model pembelajaran quantum learning berbantuan media audio visual sebagai berikut.

Tahap pertama model pembelajaran quantum learning yaitu Tumbuhkan. Tahap awal dalam proses pembelajaran yaitu menumbuhkan minat belajar dan self efficacy peserta didik. Agar peserta didik lebih semangat dan merasa senang, peserta didik bersama-sama menyanyikan yel-yel kelasnya. Selanjutnya menyampaikan tujuan dan manfaat pembelajaran serta sugesti positif guru. Pada tahap ini guru memberikan sugesti positif atau saran-saran yang mampu mengacu peserta didik untuk belajar dan secara langsung dapat mempengaruhi self efficacy peserta didik. Sejalan dengan pendapat Putra (2017), sugesti positif merupakan saran atau pengarahan positif yang dapat menggerakan hati orang-orang yang mendengarnya untuk melakukan tindakantindakan positif bagi kehidupannya. Tindakantindakan positif yang dimaksud adalah peserta didik aktif dalam pembelajaran seperti berdiskusi, tanya jawab, mencatat, dan lain sebagainya.

Tahap kedua model pembelajaran quantum learning adalah Alami. Pada tahap ini peserta didik diberikan kesempatan untuk mengeksplorasi pengalaman umum, disamping itu peserta didik diberikan kesempatan untuk mengalami proses pembelajaran. Pada saat pembelajaran peserta didik tampak berdiskusi dengan kelompoknya. Menurut Setiawan (2018), rencana kelompok adalah suatu metode yang dapat mendorong keterlibatan maksimal para peserta didik. Adanya kerjasama membuat peserta didik lebih mudah dalam menyelesaikan suatu tugas yang sulit. Taraf kesulitan sebuah tugas mampu diatasi karena peserta didik memiliki self efficacy yang merupakan pengembangan dimensi self efficacy yaitu Level. Tingkat kesulitan dari sebuah tugas (apakah sulit atau mudah) akan menentukan self efficacy. Peserta didik yang merasa mudah melakukan tugas yang sulit dapat dikatakan self efficacy peserta didik tersebut tinggi. Sebaliknya peserta didik yang tidak mampu mengerjakan tugas yang mudah, dapat dikatakan bahwa self efficacy peserta didik tersebut tergolong rendah.

Tahap ketiga model pembelajaran quantum learning yaitu Namai. Pada tahap ini peserta didik mendapatkan informasi dengan menggunakan petunjuk yang diberikan guru atau sumber lainnya Pemerolehan informasi saat pembelajaran di kelas tidak hanya bersumber dari guru ataupun buku, tetapi dapat diperoleh dari mengamati media pembelajaran yang digunakan. Pada tahap ini peserta didik mencatat hal yang ditemukan saat 
mengamati ataupun saat membaca buku. Menurut Nihayah dan Retnani (2017), mencatat merupakan salah satu aktivitas belajar. Peserta didik mencatat atau menulis poin-poin penting untuk mudah mengingat apa yang telah dipelajari. Selanjutnya peserta didik diberikan LKPD atau tugas yang dikerjakan bersama kelompoknya. Pemberian tugas dilakukan agar peserta didik aktif dalam pembelajaran. Hal ini didukung oleh pendapat Riyanto (dalam Kurnianingtyas dan Nugroho, 2012) yang menyatakan bahwa implikasi prinsip belajar bagi peserta didik agar menjadi aktif salah satunya dengan pemberia tugas maupun pemberian kesempatan untuk melaksanakan eksperimen dalam kelompok.

Tahap keempat model pembelajaran quantum learning yaitu Demonstrasikan. Pada tahap ini peserta didik diberikan kesempatan untuk menyampaikan pengetahuan atau konsep yang sedang dibahas. Saat proses pembelajaran berlangsung, sebagian besar peserta didik auntusias dan aktif untuk mengemukakan pendapatnya dan berani tampil ke depan kelas. Pada tahap ini peserta didik melatih diri untuk meningkatkan self efficacy karena pada tahap ini peserta didik mengemukakan pendapatnya serta menanggapi pendapat. Menurut Lauster (dalam Hendriana, 2012), berani mengungkapkan pendapat merupakan salah satu karakteristik untuk menilai kepercayaan diri seseorang. Berani mengungkapkan pendapat merupakan adanya suatu sikap untuk mampu mengutarakan suatu dalam diri yang ingin diungkapkan kepada orang

\section{SIMPULAN DAN REKOMENDASI}

Self efficacy merupakan keyakinan atau kepercayaan seseorang terhadap memampuan dan kompetensi diri sendiri untuk menyelesaikan suatu tugas atau masalah secara maksimal. Setiap individu, khususnya peserta didik di SD dituntut memiliki self efficacy yang baik karena di sekolah peserta didik akan banyak berinteraksi dan berperan aktif dalam pembelajaran. Dengan self efficacy yang baik peserta didik dapat mengontrol dirinya sendiri agar berhasil dalam mencapai tujuan belajar ataupun menyelesaikan suatu masalah. Namun kenyataannya berdasarkan lain tanpa adanya paksaan atau hal yang dapat menghambat pengungkapan pendapat tersebut.

Tahap kelima model pembelajaran quantum learning yaitu Ulangi. Pada tahap ini, guru menanyakan kembali tentang materi yang telah dipelajari sehingga teringat kembali dengan materi yang telah dipelajari. Menurut Lutvaidah (2016), tanya jawab merupakan bentuk interaksi langsung secara lisan antara guru dengan peserta didik. Dalam hubungan ini guru dapat mengetahui peserta didik yang mengalami kesulitan belajar dan mengenal jenis atau sifat kesulitan belajar yang dihadapi melalui tanya jawab. Selain itu peserta didik diberikan kesempatan untuk menyimpulkan apa yang telah dipelajari. Kesimpulan adalah penjelasan atau tafsiran (intepretasi) yang dibuat berdasarkan pengamatan. Menurut Suwisno (2016), ketika peserta didik mampu membuat kesimpulan, maka peserta didik tersebut memiliki apresiasi yang lebih baik terhadap lingkungan sekitar mereka.

Tahap keenam model pembelajaran quantum learning adalah Rayakan. Pada tahap ini peserta didik diberikan penghargaan berupa pujian dan tepuk tangan sehingga peserta didik merasa termotivasi dan bangga untuk lebih giat dan aktif dalam pembelajaran. Pujian merupakan suatu hal yang menyenangkan bagi peserta didik. Menurut Romas (2016), pemberian pujian akan mendorong peserta didik untuk mengulangi perbuatan yang baik atau pekerjaan yang berikutnya, sehingga peserta didik dapat mencapai hasil atau tujuan tertentu yang lebih baik.

wawancara dan observasi yang telah dilakukan, self efficacy peserta didik masih kurang. Peserta didik terlihat tidak percaya diri dalam menyampaikan pendapatnya, saat guru melontarkan pertanyaan peserta didik terlihat raguragu untuk mengancungkan tangan dan menjawab pertanyaan tersebut sehingga tergambarkan pembelajaran yang membosankan. Berdasarkan hal tersebut, hendaknya pelaksanaan pembelajaran dapat menumbuhkan dan meningkatkan self efficacy peserta didik. 
Dalam pembelajaran IPS yang masih dianggap membosankan oleh peserta didik diperlukan pemanfaatan model pembelajaran bervariasi dan inovatif yang dapat melibatkan peserta didik secara aktif dan menyenangkan. Salah satu model pembelajaran inovatif yang dapat diterapkan adalah model pembelajaran quantum learning berbantuan media audio visual. Model pembelajaran quantum learning adalah model pembelajaran yang membiasakan peserta didik belajar menyenangkan dan bermanfaat. Dimana dalam pembelajaran tersebut memadukan berbagai sugesti dan interaksi positif dengan lingkungan sehingga secara langsung dapat mempengaruhi proses belajar peserta didik. Penelitian ini bertujuan untuk mengetahui adanya pengaruh model pembelajaran quantum learning berbantuan media audio visual terhadap self efficacy peserta didik pada mata pelajaran IPS dan pembelajaran tanpa menggunakan model pembelajaran quantum learning berbantuan media audio visual terhadap self efficacy pada mata pelajaran IPS.

\section{DAFTAR PUSTAKA}

Agung, A. A. G. (2015). Metodologi Penelitian Pendidikan. Yogyakarta: Aditya Media Publishing.

Amanda, N. W. Y., Subagia, I. W., Tika, I. N., \& Si, M. (2014). Pengaruh Model Pembelajaran Berbasis Proyek Terhadap Hasil Belajar IPA Ditinjau dari Self Efficacy Siswa. Jurnal Pendidikan dan Pembelajaran IPA Indonesia, 4(1).

Asyhar, R. (2012). Kreatif Mengembangkan Media Pembelajaran. Jakarta: Referensi Jakarta.

Awasthi, D. (2014). Utilising Audio Visual Aids to Make Learning Easy and Effective in Primary Education. International Journal of Scientific Research (IJSR), 3(8).

Dantes, N. (2014). Landasan Pendidikan Ditinjau Dari Dimensi Makropedagogis. Singaraja: Graha Ilmu.

Fattah, H. (2017). Kepuasan Kinerja \& Kinerja Pegawai: Budaya Organisasi, Perilaku Pemimpin, dan Efikasi Diri. Yogyakarta: Elmatema.
Penelitian ini menggunakan rancangan Nonequivalent post-test only control grup dan analisis penelitian yang digunakan adalah Independent t-test. Penelitian ini dilaksanakan di SD Gugus III Kecamatan Tembuku, Kabupaten Bangli. Pengambilan sampel dalam penelitian ini dilakukan dengan teknik simple random sampling. Sampel penelitian ini adalahpeserta didik kelas V di SD Negeri 5 Yangapi yang berjumlah 34 orang peserta didik sebagai kelas eksperimen dan SD Negeri 1 Yangapi yang berjumlah 26 orang peserta didik sebagai kelas kontrol.

Berdasarkan uji hipotesis hasil angket self efficacy diperoleh $\mathrm{t}_{\text {hitnung }}=4.935$ sedangkan pada taraf signifikansi $5 \%$ dan $\mathrm{dk}=58$ diperoleh nilai $\mathrm{t}_{\text {tabel }}=2.001$ karena $\mathrm{t}_{\text {hitnung }}=4.935>\mathrm{t}_{\text {tabel }}=2.001$, sehingga $\mathrm{H}_{0}$ ditolak dan $\mathrm{H}_{1}$ diterima. Dengan demikian dapat disimpulkan bahwa adanya pengaruh model pembelajaran quantum learning berbantuan media audio visual terhadap self efficacy siswa kelas V pada mata pelajaran IPS SD Gugus III Kecamatan Tembuku Kabupaten Bangli tahun pelajaran 2019/2020.

Hendriana, H. (2012). Pembelajaran matematika humanis dengan metaphorical thinking untuk meningkatkan kepercayaan diri siswa. Infinity Journal, 1(1), 90-103.

Huda, M. (2014). Model-model Pengajaran dan Pembelajaran Isu-isu Metodis dan Paradigmatis. Yogyakarta: Pustaka Pelajar.

Koyan, I. W. (2012). Buku Ajar 2012: Statistik Dua: Analisis Varian, Kovarians dan Jalur. Singaraja: Universitas Pendidikan Ganesha Press.

Kurnianingtyas, L. Y., \& Nugroho, M. A. (2012). Implementasi Strategi Pembelajaran Kooperatif Teknik Jigsaw untuk Meningkatkan Keaktifan Belajar Akuntansi pada Siswa Kelas X Akuntansi 3 SMK negeri 7 yogyakarta tahun ajaran 2011/2012. Jurnal Pendidikan Akuntansi Indonesia, 10(1).

Lafudin. (2014). Belajar dan Pembelajaran Dilengkapi dengan Model Pembelajaran, 
Jurnal PAJAR (Pendidikan dan Pengajaran)

Volume 4 Nomor 4 Juli 2020 | ISSN Cetak : 2580 - 8435 | ISSN Online : 2614 - 1337

DOI : http://dx.doi.org/10.33578/pjr.v4i2.8050

Strategi Pembelajaran, Pendekatan Pembelajaran dan Metode Pembelajaran. Yogjakarta: CV Budi Utama.

Lutvaidah, U. (2016). Keefektifan Strategi Pembelajaran antara Metode Tutor Sebaya dengan Metode Tanya Jawab dalam Pengajaran Remidial Materi Fungsi Limit. Formatif: Jurnal Ilmiah Pendidikan MIPA, 6(3).

Manuntung, A. (2018). Terapi Perilaku Kognitif pada Pasien Hipertensi. Malang: Wineka Media.

Mayasari, N. (2019). Peranan Model Pembelajaran Value Clarification Technique Berbantuan Media Audio Visual Untuk Meningkatkan Hasil Belajar IPS. Jurnal Pendidikan, 20(1), 53-68.

Mukhid, A. (2009). Self-Efficacy (Perspektif Teori Kognitif Sosial dan Implikasinya terhadap Pendidikan). TADRIS: Jurnal Pendidikan Islam, 4(1).

Nihayah, L., \& Retnani, W. (2017). Manfaat Hipnoterapi Terhadap Minat Belajar Bagi Siswa Kelas VI Sekolah Dasar. Psikologia: Jurnal Psikologi, 1(1), 3-21.

Notoatmodjo, S. (2003). Pendidikan dan Perilaku Kesehatan. Jakarta: Rineka Cipta.

Putra, H. P. (2017). Peningkatan Self Esteem Siswa Melalui Layanan Bimbingan Kelompok Dengan Teknik Sugesti. Islamic Counseling: Jurnal Bimbingan Konseling Islam, 1(1), 95-111.

Putra, I. K. R., Rati, N. W., \& Murda, I. N. (2019). Pengaruh Model Pembelajaran Quantum Learning Berbantuan Peta Pikiran Terhadap Kemampuan Berpikir Kreatif Dan Hasil Belajar IPS Siswa Kelas V. Jurnal Pendidikan IPS Indonesia, 3(1), 42-52.

Romas, M. Z. (2016). Pengaruh pujian terhadap prestasi belajar matematika pada siswa kelas 4 Sekolah Dasar. Jurnal Psikologi, 2(1).

Santoso, S. D. (2011). Peningkatan Keterampilan Menulis Deskripsi Dengan Penerapan Metode Quantum Learning Pada Siswa Kelas IV SD Negeri Japanan 2 Klaten
Tahun Ajaran 2010/2011. Doctoral Dissertation. Universitas Sebelas Maret.

Subaidi, A. (2016). Self-efficacy siswa dalam pemecahan masalah matematika. Sigma, 1(2), 64-68.

Suwisno, E. N. (2016). Efektivitas Model Discovery Learning pada Materi Larutan Penyangga dalam Meningkatkan Keterampilan Memprediksi dan Menyimpulkan. Skripsi. Universitas Lampung.

Thobroni. (2015). Belajar dan Pembelajaran. Yogyakarta: Ar-Ruzz Media

Utari, A. R. (2016). Pelatihan Efikasi Diri Islami untuk Menurunkan Kecemasan Lingkungan Baru pada Siswa SMP Muhammadiyah 3 Yogyakarta. In Prosiding Seminar Nasional" Optimalisasi Peran Pendidikan dalam Membangun Karakter Anak untuk Menyongsong Generasi Emas Indonesia" (pp. 400-404). Prodi BK dan PGSD FKIP UAD. 